\title{
If Addiction is a Mental Disease, Let's Start TREATING IT LIKE ONE: AN ADDITIONAL RECOMMENDATION FOR THE INDIANA GENERAL Assembly's Prenatal Substance Abuse Commission
}

\author{
Matthew Derringer*
}

I. INTRODUCTION 142

II. BACKGROUND: PRENATAL SUBSTANCE ABUSE AND

GOVERNMENTAL INTERVENTION

A. The Debate at its Core: Two Sides of the Coin......................... 144

B. Development of Governmental Intervention ............................... 145

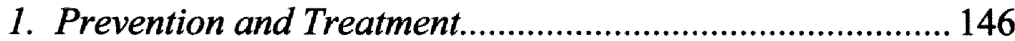

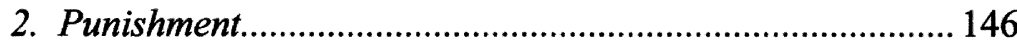

a. Criminal prosecution in general .................................. 147

b. Criminal prosecution in Indiana: One small step ........ 148

C. Indiana's Current Judicial Approach to Pregnant

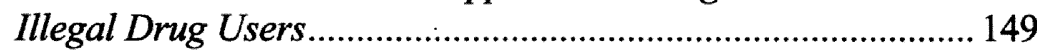

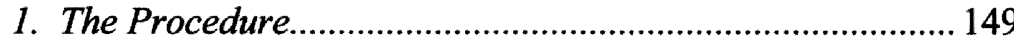

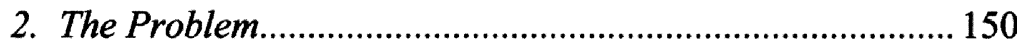

D. A More Recent Analysis of Indiana's Governmental

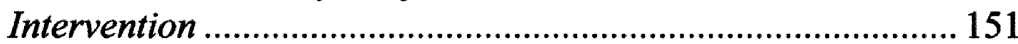

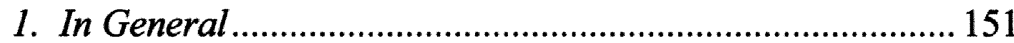

2. Alcohol, Tobacco, and Drug Use by Pregnant Women in Indiana 2006 Study ....................................................... 152

3. Prenatal Substance Abuse Commission: 2009 Final Report.

III. ANALYSIS: AN ADDITIONAL RECOMMENDATION: RECOGNIZING THE CONCEPT OF ADDICTION AS A MENTAL DISEASE .....................155

A. Addiction as a Mental Disease ................................................ 155

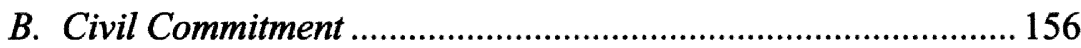

1. Indiana's Civil Commitment Framework .............................156

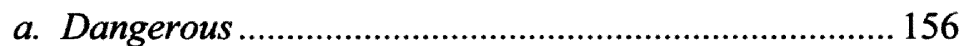

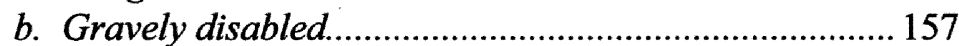

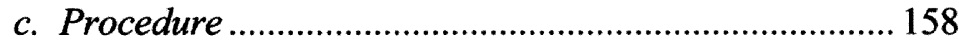

2. Civil Commitment in Other States .....................................160

3. Legislative Will and Public Policy........................................ 161

a. Recent Indiana legislation.............................................. 161

b. Public Policy and the United States Supreme Court.... 162

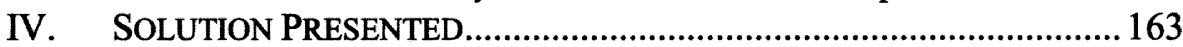

A. Application of Existing Law ...................................................... 163

* J.D. Candidate, 2011, Indiana University School of Law - Indianapolis; B.A., 2003, Ball State University. 
B. Clarification and Expansion of Existing Law

C. A Possibility for Future Legislative Action and Response to Opposing Viewpoints.

1. For Consideration: A Point of Agreement with the Prenatal Substance Abuse Commission Final Report

2. Opposing Viewpoints 166

V. CONCLUSION 168

\section{INTRODUCTION}

On August 15, 2009, the Indiana General Assembly's Prenatal Substance Abuse Commission issued a Final Report, the culmination of over three years of research and analysis, and part of the State's "continued effort to improve the outcomes of pregnanc[ies] in Indiana." The Final Report, discussed in detail below, included findings and recommendations for the General Assembly's consideration in formulating a more thorough legislative response to the use of alcohol, tobacco, and illegal drugs by pregnant women in Indiana. ${ }^{2}$ Recommendations the General Assembly intend to consider during future legislative sessions, however, remain to be seen.

The use of alcohol, tobacco, and illegal drugs by pregnant women is a significant public health issue in Indiana as well as all other states. Although numbers vary, recent estimates in Indiana show that approximately twenty percent of pregnant women smoke cigarettes, ten percent use alcohol, and five to six percent use illegal drugs. ${ }^{3}$ However, a significant obstacle to this issue is a state's legal ability to address the behavior. After all, use of alcohol and tobacco by adults is not usually illegal behavior, even by pregnant women. Further, there does not seem to be any intention in Indiana to prohibit such behavior. Illegal drug use by pregnant women is perhaps the only behavior of the three issues mentioned above, that a state, and Indiana in particular, could approach through a legal framework because the root of the problem involves activity which is already illegal in every state. Therefore, the recommendations proposed in the Prenatal Substance Abuse Commission's Final Report involving illegal drug use by pregnant women in Indiana should be carefully considered.

1. Ind. Prenatal Substance Abuse Comm'n, Final Report: Findings and RECOMMENDATIONS 4 (2009), available at $\mathrm{http} / / \mathrm{w} w \mathrm{w}$.in.gov/legislative/senate_democrats/ files/PSACFinalReport.081509.pdf.

2. See generally id.

3. TeRrell W. Zollinger, et Al., Ind. Univ. School of Med., Alcohol, Tobacco and DRug Use by Pregnant Women IN INDIANa: A Study for the Indiana STate DEPARTMENT OF HEALTH 5 (2006), available at http://www.in.gov/legislative/igareports/ agency/reports/ISDOH30.pdf; see also Page Mcguire Linden, Drug Addiction During Pregnancy: A Call for Increased Social Responsibility, 4 AM. U. J. GENDER \& L. 105, 107 (1995) ("[A]pproximately eleven percent of all pregnant women have used illegal drugs while pregnant, and of those eleven percent, seventy-five have used cocaine during a pregnancy."). 
Proposals have been developed for the General Assembly's review due to various problems with the current approach to the issue of illegal drug use during pregnancy. The current approach in Indiana does not take into account the emerging, medically validated assertion that chemical addiction is a mental illness. There is also a lack of recognition that under Indiana law, addiction is categorized as a mental illness. ${ }^{4}$ The proposed approach included herein, detailing the legislative framework and procedure for civil commitment in the context of mental illness in Indiana, could also be employed for pregnant illegal drug users. Addiction is considered a mental illness in Indiana, and the state should begin treating it as such. ${ }^{5}$ The consequence of unchecked addictions of pregnant drug users is an individual who is not only mentally ill but who is also dangerous to the point of presenting a substantial risk to another-the unborn fetus. The approach proposed here is a narrowly tailored governmental intervention which serves a compelling state interest in the protection of unborn fetuses.

As demonstrated in the two cases below, there are a wide range of beliefs as to how prenatal substance abuse should be addressed. As is often the case in our country, there are almost as many different governmental approaches to the problem as there are states. ${ }^{6}$ This begs the question: where does Indiana stand in the debate? This Note considers whether Indiana's current response is effective in mitigating the harm caused when pregnant women use illegal drugs, and whether there is a more efficient legislative and procedural framework, either under current statutes or which could be enacted, that could be adopted by Indiana in an effort to further protect the future lives of unborn children exposed to drugs by chemicallyaddicted, mentally ill mothers.

Part II of this Note discusses the development of governmental responses to the issue of prenatal substance abuse in general, and details Indiana's current approach to the issue. Part II also examines a 2006 study conducted by the Indiana University School of Medicine for the Indiana State Department of Health, which led to the Indiana General Assembly's creation of the Prenatal Substance Abuse Commission and that panel's subsequent Final Report. Part III analyzes the concept of addiction as a mental disease, and is followed by a detailed analysis of the legal framework and policy implications for civil commitment, and the feasibility of enacting a different approach in Indiana. Part IV presents solutions for the issues raised in this Note, as well as a discussion of opposing viewpoints. The Note is concisely concluded in Part V with a brief final thought.

4. See, e.g., Ind. Code $\S 12-7-2-130$ (2010).

5. See infra Part III.A.

6. See Addington v. Texas, 441 U.S. 418, 431 (1979) ("The essence of federalism is that states must be free to develop a variety of solutions to problems and not be forced into a common, uniform mold."). 


\section{BACKGROUND: PRENATAL SUBSTANCE ABUSE AND GOVERNMENTAL INTERVENTION}

\section{A. The Debate at its Core: Two Sides of the Coin}

The issue of a state's legal response to the use of illegal drugs by pregnant women usually arises when a high profile case gets extensive media coverage and a segment of the populace becomes outraged at the lack of emphasis on personal responsibility on the pregnant mother's part. Take, for instance, the highly publicized 2005 case of Tayshea Aiwohi in Hawai'i. In 2004, Ms. Aiwohi was convicted of manslaughter, partly due to her admission to smoking crystal methamphetamine for four days up to and including the day she gave birth to Treyson Aiwohi on July 15, 2001. Treyson Aiwohi died two days later, on July 17, 2001, and the medical examiner testified in the grand jury proceeding that the cause of Treyson's death was the toxic effects of methamphetamine, "consistent with exclusive prenatal exposure through the mother."8

In its unanimous November 29, 2005 decision, the Supreme Court of Hawai'i reversed Ms. Aiwohi's conviction, holding that a fetus is not within the statutory definition of "person" for the purposes of a manslaughter charge in Hawai'i. ${ }^{9}$ Therefore, the court reasoned that Ms. Aiwohi could not be convicted for her prenatal use of illegal drugs because Treyson Aiwohi was not a "person" at the time of the proscribed conduct. ${ }^{10}$ While citing examples from seven states, the Supreme Court of Hawai'i stated, "An overwhelming majority of the jurisdictions confronted with the prosecution of a mother for her own prenatal conduct, causing harm to the subsequently born child, refuse to permit such prosecutions."11

In contrast to Aiwohi, is the South Carolina case of Cornelia Whitner. ${ }^{12}$ In 1992, Ms. Whitner was convicted of criminal child neglect due to her ingestion of crack cocaine during the third trimester of her pregnancy. ${ }^{13}$ She was sentenced to eight years in prison. ${ }^{14}$ Similar to the Aiwohi case, the question in Whitner arose as to whether the word "child" in South Carolina's child abuse and endangerment statute encompassed an unborn fetus. ${ }^{15}$ The result, however, was quite different from Aiwohi. In 1997, the Supreme Court of South Carolina held that the term "child" does include "via-

7. State v. Aiwohi, 123 P.3d 1210, 1210-11 (Haw. 2005).

8. Id.

9. Id. at 1224 .

10. Id. (noting "[e]ven if, arguendo, the statutory language were perceived to be ambiguous, the term 'person' may not be construed so as to include fetuses.").

11. Id. at 1214 .

12. Whitner v. State, 492 S.E.2d 777, 778-79 (S.C. 1997).

13. Id.

14. Id.

15. Id. at 778 . 
ble fetuses," stating, "we do not see any rational basis for finding a viable fetus is not a 'person' ... [i]ndeed, it would be absurd to recognize the viable fetus as a person for purposes of homicide laws and wrongful death statutes but not for purposes of statutes proscribing child abuse."16 Further, the court stated that to hold as such was a continuation of long-standing established law in the state. ${ }^{17}$ The court also recognized its relatively unique position on the issue, stating, "We are well aware of the many decisions from other states' courts throughout the country holding maternal conduct before the birth of the child does not give rise to criminal prosecution under state child abuse/endangerment or drug distribution statutes." The United States Supreme Court denied certiorari. ${ }^{19}$ Needless to say, South Carolina was not one of the seven states the Aiwohi court cited in its survey of the "majority" of states who refuse to permit prosecution of mothers for prenatal conduct. ${ }^{20}$

\section{B. Development of Governmental Intervention}

The dangers of illegal drug use during pregnancy are well documented, but the problem became nationally recognized in the 1980's after the explosion of crack cocaine use produced the media handle "crack babies" for children born from these unfortunate situations. ${ }^{21}$ Heroin use has also been implicated in the context of harm to the unborn child. ${ }^{22}$ More recently, the rapid increase in methamphetamine use in the United States has come into the focus of state legislatures, though studies are still being conducted to determine the exact effects of prenatal methamphetamine use. ${ }^{23}$ Regardless of the illegal drug in question, one can assume that prenatal substance

16. Id. at 780; accord LA. REv. STAT. ANN. § 14:2(A)(7) (2008) (“'Person' includes a human being from the moment of fertilization and implantation....").

17. Whitner, 492 S.E.2d at 779 ("South Carolina law has long recognized that viable fetuses are persons holding certain legal rights and privileges.").

18. Id. at 782.

19. Whitner v. South Carolina, 523 U.S. 1145 (1998).

20. State v. Aiwohi, 123 P.3d 1210, 1214 (Haw. 2005) (the seven states cited include New York, Ohio, Texas, Arizona, Washington, Florida, and Wisconsin).

21. Ferguson v. City of Charleston, 532 U.S. 67, $70 \mathrm{n} .1$ (2001) ("[T] he problem of 'crack babies' was widely perceived in the late 1980's as a national epidemic, prompting considerable concern both in the medical community and among the general populace.").

22. See Linden, supra note 3, at 108. ("Many of the adverse effects on fetal development associated with cocaine use during pregnancy also apply to use of heroin and other narcotics by pregnant women.").

23. See Linda C. Fentiman, In the Name of Fetal Protection: Why American Prosecutors Pursue Pregnant Drug Users (And Other Countries Don't), 18 CoLUM. J. GENDER \& L. 647,655 (2009) ("Today, sensational reports about methamphetamine abuse frequently make headlines across the United States, and law enforcement officers and the media frequently profess its harmful effects on users, their children, and fetuses. However, there is little data demonstrating a causal relationship between exposure to methamphetamine in utero and problems of infant development. "). 
abuse does nothing but put unborn fetuses in a less than optimal gestation situation. In most instances of prenatal substance abuse, states approach the issue from one of two ends of the spectrum: prevention and treatment, or punishment.

\section{Prevention and Treatment}

Most states overwhelmingly prefer prevention and treatment approaches to the problem over punishment. ${ }^{24}$ Almost every state has at least one government-mandated program aimed at educating pregnant women about the dangers of prenatal illegal drug use. ${ }^{25}$ From the prevention aspect, approaches can focus either on preventing pregnant women in general from using illegal drugs or preventing women of childbearing age from using illegal drugs. The treatment approach is "in keeping with evidencebased medical recommendations that support treatment approaches to drug use or addiction, not punitive ones." 26 Further, "[a]ddiction research has found that treatment and education strategies are effective and less costly than punitive ones." 27 Typical substance abuse treatment programs consist of a brief detoxification period ("detox"), outpatient treatment where the individual attends group meetings once per week, intensive outpatient treatment involving attendance at group meetings three times per week, or inpatient treatment at a facility dedicated to around-the-clock substance abuse treatment. ${ }^{28}$ In either the prevention or treatment approaches, resources are expended by the state with the hope that pregnant substance abusers will recognize the dangers involved with their behavior and enact a change.

\section{Punishment}

Punishment is the minority approach to the issue, but it is not without innovative avenues toward implementation, and often strong public support. $^{29}$ When expecting or new mothers are prosecuted for alleged acts

24. See ZolLINGER, ET AL., supra note 3, at 6 (noting, "[T]reatment programs exist in all states.").

25. Lynn M. Paltrow et al., Governmental Responses to Pregnant Women Who Use Alcohol or Other Drugs - Year 2000 Overview, Part 1, Women's L. Project AND Nat'L ADVOCATES FOR PREgnant WOMEN (last updated Oct. 2000), http://www.drugpolicy.org/ library/gov_responses_overview_p1.cfm.

26. Lisa H. Harris \& Lynn Paltrow, The Status of Pregnant Women and Fetuses in U.S. Criminal Law, 304 JAMA 1697, 1698 (2003).

27. Id.

28. See generally SUBSTANCEABUSECENTERS.COM, http://www.substanceabusecenter .com/indiana/ (last visited Mar. 13, 2010).

29. See Mark Curriden, Holding Mom Accountable: Roe v. Wade Does Not Prevent Criminal Prosecution of Prenatal Child Abuse, 76 A.B.A. J. 50, 51 (1990) ("A survey of 15 southern states by the Atlanta Constitution found that 71 percent of the 1,500 people polled 
committed during pregnancy, those attempted prosecutions "are generally premised on one of the following concepts: delivery of a controlled dangerous substance to a minor, child endangerment, child abuse, and homicide by child abuse." for potential fetal harm, courts are asked to determine if existing criminal statutes can be expanded and applied to pregnant women's behavior and health conditions." $"$ It is this statutory wrangling which usually presents the main problem for prosecutors. Additionally, there is the perceived problem that by proscribing a pregnant woman's conduct, "the logic of allowing such prosecutions would be extended to cases involving smoking, alcohol ingestion, the failure to wear seatbelts, and any other conduct that might cause harm to a mother's unborn child."32 Further still, even in jurisdictions where prosecutions can be sustained, fear of criminal prosecution could deter desirable behavior like seeking out prenatal medical service throughout pregnancy and hospitalization at the time of birth for fear of criminal prosecution. ${ }^{33}$

\section{a. Criminal prosecution in general}

As mentioned in the Whitner case above, there are instances of women being criminally prosecuted and convicted for their prenatal use of illegal drugs. Eleven states, other than Indiana, have attempted prosecutions of

favored criminal penalties for pregnant women whose illegal drug use injures their babies.").

30. Wade L. House, Article, State v. Armstard: A Call To Arms For the Defense of Children, 36 S.U. L. REV. 263, 267 (2009); see also Krista Stone-Manista, Comment, Protecting Pregnant Women: A Guide to Successfully Challenging Criminal Child Abuse Prosecutions of Pregnant Drug Addicts, 99 J. Crim. L. \& Criminology 823, 824 (2009) ("Prosecutors bring criminal charges against pregnant women who use illicit drugs under a wide range of state statutes, including but not limited to those governing criminal child abuse, criminal child mistreatment, and attempted first-degree intentional homicide.").

31. Harris \& Paltrow, supra note 26, at 1697; see also Linden, supra note 3, at 120 ("In theory, the use of abuse and neglect statutes does further the goal of maintaining the mother-child relationship with the primary goal of state intervention under these statutes being reunification of the family.").

32. State v. Wade, 232 S.W.3d 663, 666 (Mo. Ct. App. 2007); see also Lynn M. Paltrow, Pregnant Drug Users, Fetal Persons, and the Threat to Roe v. Wade, 62 ALB. L. REV. 999, 1021-22 (1999) ("Virtually no state ... punishes drug use per se. As a result, the prosecutors are in fact seeking to have the judiciary create a new crime of drug use, and then only for one group of people--pregnant women."); $c f$. Tiffany Lyttle, Note, Stop the Injustice: A Protest Against the Unconstitutional Punishment of Pregnant Drug-Addicted Women, 9 N.Y.U. J. LEGIS. \& PUB. PoL'Y 781, 783 (2006) ("[A] State's punishment of a drug-addicted woman for her actions during pregnancy violates the Eighth Amendment's Cruel and Unusual Punishment Clause because the State is penalizing the woman for her status as a drug addict.").

33. Carol Gosain, Protective Custody for Fetuses: A Solution to the Problem of Maternal Drug Use? Casenote on Wisconsin Ex Rel. Angela v. Kruzicki, 5 GEO. MASON L. REV. 799,839 (1997) ("Data indicates [sic] that criminal prosecutions of women who abuse drugs during pregnancy have resulted in an increase in the number of unsupervised births taking place outside hospitals."); see also Linden, supra note 3, at 120 ("Failure to receive prenatal care is extremely harmful to both mother and fetus."). 
women based on their prenatal drug use. ${ }^{34}$ What is significant about Whitner is that the prosecution proceeded under the South Carolina statute pertaining to the unlawful conduct towards a child, which is, in essence, a child abuse statute. ${ }^{35}$ It was the Whitner court's interpretation that "child" included "viable fetuses" which allowed the prosecution to stand, in direct contrast to the finding by the Aiwohi court, which resulted in Ms. Aiwohi's conviction being reversed. It would seem that courts would have to make the determination on a state-by-state basis as to whether or not a viable fetus is considered a "child" for each child abuse statute, or for any other statute a prosecutor might attempt to use in criminally charging a pregnant substance abuser.

\section{b. Criminal prosecution in Indiana: One small step}

Indiana courts have made the determination with regard to the child abuse statute listed in section 35-46-1-4 of the Indiana Code (Neglect of a Dependent), that, similar to Hawai' $i$, the term "dependent" does not include an unborn child. ${ }^{36}$ As such, attempts to prosecute pregnant women under the Indiana child abuse statutes often do not result in sustainable convictions. However, one Indiana court addressing the issue seemed to imply that an amendment of the statute by the Indiana General Assembly to expressly include unborn children within the definition of "dependent" would be all that is required for Indiana courts to apply a standard similar to the South Carolina standard in Whitner. ${ }^{37}$ With such an amendment, there does not seem to be much more for an Indiana court to interpret. The Herron court specifically stated, "We cannot expand the General Assembly's definition of a dependent and, consequently, the intended application of the neglect of a dependent statute, beyond the fair meaning of the words used. Sections 35-46-1-1 and 35-46-1-4 of the Indiana Code do not criminalize conduct that occurs prior to a child's birth." ${ }^{38}$ This language signaled that a legislative amendment to the statutes in question would make convictions of pregnant women for using illegal drugs under the child abuse statutes in Indiana sustainable. However, criminal prosecutions of pregnant drug users have

34. House, supra note 30, at 268-72 (the states: Florida, Michigan, Pennsylvania, Texas, Ohio, Nevada, Maryland, Missouri, Kentucky, Louisiana and South Carolina).

35. See Whitner v. State, 492 S.E.2d 777, 778 (S.C. 1997); S.C. CodE ANN. § 63-5-70 (2008). See generally Richard Karel, Punishing Pregnant Women Who Abuse Drugs Doesn't Work, PsYCHIATRIC News, Oct. 16, 1998, http://www.psychiatricnews.org/pnews/98-1016/pregnant.html ("The Whitner case has become a rallying point for both opponents and proponents of punitive, coercive interventions for pregnant substance abusers.").

36. Robinson v. State, 894 N.E.2d 1038, 1042 (Ind. Ct. App. 2008) ("[T]he definition of 'dependent,' as used in this statute, does not include an unborn child"); See IND. CODE $\S$ 35-46-1-4 (2004).

37. Herron v. State, 729 N.E.2d 1008, 1011 (Ind. Ct. App. 2008).

38. Id. 
been widely criticized and are not without drawbacks. Further, Indiana has shown a preference for a non-criminal approach in its current procedure for addressing the issue.

\section{Indiana's Current Judicial Approach to Pregnant Illegal Drug Users}

\section{The Procedure}

In Indiana, the current state response for when a newborn child tests positive for illegal drugs falls within the statutory area of family and juvenile law. The Indiana Code defines circumstances under which a child born with any amount of an illegal substance in their body can be determined a "child in need of services" ("CHINS"). 39 In such a situation, an immediate oral report must be made to the Department of Child Services ("DCS") or the local law enforcement agency for the beginning of investigative action. ${ }^{40}$

Indiana law also provides a statutory abrogation of privileged relationships, including doctor-patient and attorney-client privileges, which effectively dispenses with any question of whether the report could be made in the first place. ${ }^{41}$ Furthermore, Indiana makes it a Class B Misdemeanor to knowingly fail to make this report. ${ }^{42}$ DCS is required to prepare a written report within forty-eight hours of receiving notification via the oral report. ${ }^{43}$ If a report is substantiated, the most severe option available is the filing of a CHINS petition, which invokes the jurisdiction of the juvenile courts to proceed with legal action, could lead to the termination of parental rights. ${ }^{44}$ Indiana courts have clarified that, "[t]he purpose of terminating parental rights is not to punish a parent but to protect the child." 45

The Indiana case In re C.S. is a working example of this approach. ${ }^{46}$ In that case, a child was born on November 25, 2005, at which time the mother, Loretta Savage, tested positive for opiates and benzodiazepines and the newborn also tested positive for benzodiazepines. ${ }^{47}$ The drug test re-

39. IND. CODE $§ 31-34-1-10$ (2008) ("the child is born with: any amount, including a trace amount, of a controlled substance or a legend drug in the child's body"); $\$ 31-34-1-11$ ("the child: has an injury; has abnormal physical or psychological development; or is at a substantial risk of a life threatening condition; that arises or is substantially aggravated because the child's mother used alcohol, a controlled substance, or a legend drug during pregnancy.").

40. See $\S 31-33-5-4$.

41. See IND. CODE § 31-32-11-1 (2009).

42. IND. CODE $\S 31-33-22-1$ (2008).

43. IND. CODE $§ 31-33-7-4$. (2008).

44. Ind. Code $§ 31-33-7-7$ (2009).

45. In re I.A., 903 N.E.2d 146, 152 (Ind. Ct. App. 2009).

46. In re C.S., 863 N.E.2d 413 (Ind. Ct. App. 2007).

47. Id. at 414-15; see also Benzodiazepines, U.S. DRUG ENFORCEMENT ADMIN., 
sults were subsequently forwarded to DCS. ${ }^{48}$ A DCS investigator interviewed Loretta Savage at the hospital, during which Ms. Savage admitted to using drugs during her pregnancy. ${ }^{49}$ DCS then filed a CHINS petition, four days after the birth of the newborn. ${ }^{50}$ Judicial action was swift: "[a]n initial hearing was held that same day at which Savage admitted the allegations of the petition and C.S. was placed in foster care."

\section{The Problem}

The problem with the current approach in Indiana is that it is designed to deal with the problem after the birth of the child who has been exposed to illegal drugs. Although Indiana's current approach deals retroactively with illegal drug use during pregnancy, Indiana has never confronted the following question: What should a state do, if anything, with pregnant women who use illegal drugs during pregnancy? Although Indiana still has yet to address this problem, a few other states have. The goal should be to eliminate exposing fetuses to illegal drugs during pregnancy, while fostering an environment in which the mother can address her addiction. This should be accomplished so as to enable the mother and child to remain together after the birth.

Under the current statutory interpretation of most state child abuse statutes, most recently considered in Herron, ${ }^{52}$ it is evident that the criminal prosecution of prenatal drug abusers generally will not be successful. ${ }^{53}$ However, this roadblock to criminal prosecution may not necessarily be bad, because there is, perhaps, another set of statutes which would be more useful in prevention of this harmful prenatal exposure to illegal drugs:

An overloaded criminal justice system that cannot adequately respond to increased drug abuse-related criminal offenses, and perceptions that the criminal justice system may not be the appropriate means for responding to drug abusers, has highlighted the potential of civil commitment as an important and distinct alternative for dealing with drug abuse. ${ }^{54}$

http://www.justice.gov/dea/concern/benzodiazepines.html (last visited Jan. 2, 2011) (Benzodiazepines are typically ingested as prescription medication, such as Xanax or Valium).

48. In re C.S., 863 N.E.2d at 414-15.

49. Id.

50. Id.

51. Id.

52. Herron v. State, 729 N.E.2d 1008, 1011 (Ind. Ct. App. 2008).

53. Fentiman, supra note 23, at 647 ("In all but three states-Alabama, Kentucky, and South Carolina-such prosecutions have been declared unconstitutional or the resulting convictions have been overturned.").

54. Ali John Amirshahi \& Thomas L. Hafemeister, Civil Commitment for Drug De- 
Specifically, there is a possibility that civil commitment, as a kind of middle ground in the prevention/treatment-punishment spectrum, could become an effective tool in limiting prenatal exposure to illegal drugs. As a first step, however, it would be useful to examine how Indiana has reconsidered the government's position on this issue in recent years.

\section{A More Recent Analysis of Indiana's Governmental Intervention}

\section{In General}

There is no shortage of information or opinions on how and who should take action in situations involving pregnant illegal drug users, specifically through the judicial system. As is usually the case with any issue, all sides tend to make valid points. Proponents of governmental intervention cite multiple policy reasons to support such intervention, such as the need to "deter or prevent drug abuse during pregnancy, provide appropriate punishment to women deserving of such, or achieve improvements in maternal or fetal health outcomes." 55 Among other arguments, opponents of judicial intervention often suggest that most attempts are done through forced interpretations of statutes not specifically tailored to address the issue of prenatal substance abuse (i.e., child abuse and neglect statutes). ${ }^{56}$ These are just a few reasons usually cited in support of both sides of the issue. $^{57}$ The legislature is tasked with, "balancing a woman's right to bodily integrity with society's interest in ensuring healthy pregnancies, and the question of whether punitive approaches will foster-or hinder-healthy outcomes for women and children." 58 Such an important balancing act often results in a commissioned study to analyze the issue.

pendency: The Judicial Response, 26 LoY. L.A. L. REV. 39, 42 (1992).

55. Stone-Manista, supra note 30 , at 825.

56. See generally id.

57. Id. at 837 (summarizing both sides: "Pregnant women have been subjected to incarceration or other criminal sanctions for a variety of reasons: to prevent them from having access to illegal drugs, to compel them to carry their pregnancies to term, to force them to submit to a physician's orders regarding their care, or to allow the courts in other ways to control and direct a woman's conduct during her pregnancy. Instead of improving access to comprehensive maternal and child prenatal care and thus benefiting the fetus and the mother, incarceration of pregnant women may actually result in serious harm, either by restricting access to prenatal care or exposing them to less-than-ideal conditions within the prison itself. Incarceration of pregnant women does not help them to overcome their addictions, nor does it serve to protect their fetuses from drug use, as illegal drugs are readily available in prison. Although some may argue that women in prison would have better access to prenatal care than they could afford or would choose to seek out otherwise, prisons are not prepared to offer adequate care to pregnant women. ").

58. Cynthia Dailard \& Elizabeth Nash, The Guttmacher Report on Public Policy: State Responses to Substance Abuse Among Pregnant Women, Dec. 2000, at 3, available at http://www.guttmacher.org/pubs/tgr/03/6/gr030603.pdf. 


\section{Alcohol, Tobacco, and Drug Use by Pregnant Women in Indiana 2006 Study}

Indiana's approach to the issue of prenatal substance abuse indicates opposition toward judicial intervention, placing the emphasis on raising awareness and focusing on treatment and prevention. At the direction of the Indiana General Assembly, a study was conducted in 2006 by the Indiana University School of Medicine for the Indiana State Department of Health as a comprehensive look at the issue of alcohol, tobacco, and drug use by pregnant women in Indiana. ${ }^{59}$ The report indicated that while the exact prevalence of substance use during pregnancy in Indiana is unknown due to a lack of valid and timely data, an estimate based on birth certificate data puts the rate of illegal drug use by pregnant women in Indiana at approximately five to six percent. $^{60}$ The report notes that this figure likely underestimates the actual figure because it only reflects self-reported illegal drug use. ${ }^{61}$

The report also stated that there is general agreement that "the best strategy to reduce the consequences of [alcohol, tobacco, and drug] use during pregnancy is to focus on preventing women of childbearing age from using these substances." 62 In focusing on substance abuse in general, the report specifically noted that, "[i]t should also be stressed that substance use is a biomedical problem and not a character flaw."63 This position follows the trend in medical and drug treatment fields to break away from treating alcoholism and drug addictions as personal choices made by those affected and to move toward classifying the conditions as medical and mental afflictions:

Experts at the National Institute on Alcohol Abuse and Alcoholism and National Institute on Drug Abuse confirm that addiction is not primarily a moral weakness, as it has been viewed in the past, but a "brain disease" that should be included in a review of symptoms just like any other biologic disease process. ${ }^{64}$

In light of the data analyzed for the study, the report emphasized that the future direction for the State of Indiana in addressing the use of alcohol,

59. ZOLLINGER, ET AL., supra note 3, at 5 .

60. $I d$.

61. Id.

62. Id. at 114 .

63. Id.

64. Id. (quoting American College of Obstetricians and Gynecologists, ACOG Committee Opinion No. 422: At-risk Drinking and Illicit Drug Use: Ethical Issues in Obstetric and Gynecologic Practice, 112 OBSTETRICS \& GYNECOLOGY 1449, 1450 (2008).). 
tobacco, and drugs by pregnant women should focus on prevention and treatment services. ${ }^{65}$ Focusing on prevention and treatment programs "will result in reduced burdens on the health care system and law enforcement agencies." in order to address the issue, stating:

It will be essential to establish a state task force which includes state and local policy makers; administrators from public health, mental health and addiction, child welfare, health, education, employment security, criminal justice, and advocacy agencies; representatives from program funding organizations; primary care and [alcohol, tobacco, and drug] treatment providers; as well as women who used [alcohol, tobacco, and drugs] during pregnancy, to work in unison to remedy these problems. This task force will need to address the prioritization of the above issues and develop a state implementation plan to improve early intervention and treatment for pregnant women using [alcohol, tobacco, and drugs]. ${ }^{67}$

\section{Prenatal Substance Abuse Commission: 2009 Final Report}

Following the 2006 study, the Indiana General Assembly established the Prenatal Substance Abuse Commission, with a two year mission to result in a "final report that contains the findings and recommendations of the commission and an implementation plan to improve early intervention and treatment for pregnant women who abuse alcohol or drugs or use tobacco," to be submitted no later than August 15, 2009. ${ }^{68}$ The members of the Commission included directors of public health agencies, doctors specializing in the care of pregnant women and addiction treatment of pregnant women, legislators, a prosecuting attorney, a judge, and a nurse specializing in addiction treatment of pregnant women. ${ }^{69}$ The August 2009 Prenatal Substance Abuse Commission's Final Report expressed in numbers the impact of prenatal substance abuse in Indiana. With approximately 90,000 deliveries per year in the state, "[o]ver $90 \%$ [sic] of pregnant substance users in Indiana go undetected." Prenatal substance abuse can lead to pre-

65. See ZOLLINGER, ET AL., supra note 3, at 120.

66. Id.

67. Id.

68. IND. CoDE § 5-14-6-3 (P.L. 193-2007, Sec. 5) (2007).

69. InD. PRENATAL SUBSTANCE ABUSE COMM'N, supra note 1, at 6 .

70. Id. at 3 . 
term delivery of the baby (a delivery before 37 weeks). ${ }^{71}$ Put in economic terms: "With a reduction in preterm deliveries, where the average newborn nursery cost for one pre-term baby is $\$ 50,000$, the savings . . alone would be in the millions of dollars."72 Note that the savings are only in terms of the reduction of regular pre-term births. ${ }^{73}$ The savings would be compounded when factoring in the additional savings to be had in the reduction of pre-term, chemically-exposed births, with estimates that the costs of lifetime care for such children range from $\$ 750,000$ to $\$ 1.4$ million per child. ${ }^{74}$

With regard to treatment and prevention, the report stated: "The state of Indiana currently funds multiple programs specifically targeted to pregnant women in need of substance abuse and addiction services. However, there is evidence through program enrollment data and underutilized residential beds that the process to access these resources needs to be improved."75 The Prenatal Substance Abuse Commission offered the several recommendations for legislative consideration, including:

1. Implementing universal . . . verbal screening, intervention and continuous monitoring for pregnant women who screen positive, and appropriate referral for treatment.

2. Establishing a routine in-depth surveillance study to estimate prevalence of . . . use among pregnant women.

3. Establishing an ongoing cross-agency committee to monitor existing resources, improve collaboration, and carry forward the work of the Commission.

4. Designate funding to support ongoing training of prenatal providers on universal screening ....

5. Authorize funding for surveillance studies to monitor the prevalence of [alcohol, tobacco, and drug] use among pregnant women in Indiana . . . .

6. Authorize funding .... to implement the [above] [r]ecommendations. . . . [and] establishing of a crossagency committee within state government to minimize duplication of services, update resource and service information, improve coordination and

71. Id.

72. Id.

73. Id.

74. Christopher J. Kalotra, oJP Drug Court Clearinghouse AND Technical Assistance Project: Estimated Costs Related to the Birth of a Drug and/or ALCOHOL EXPOSED BABY 1 (Mar. 2002), available at http://indianaperinatal.org/downloads /Estimatedcosts.pdf; see also IND. PRENATAL SUBSTANCE ABUSE COMM'N, supra note 1, at 6.

75. IND. PRENATAL SUBSTANCE ABUSE COMM'N, supra note 1, at 11. 
collaboration in seeking grant funding and otherwise oversee the continuation of efforts to address this problem in Indiana. ${ }^{76}$

The report does not mention all of the possibilities of judicial intervention for the involuntary implementation of substance abuse treatment for prenatal drug abusers. This clearly demonstrates that the focus in the State of Indiana has been and will seemingly continue to be on prevention and treatment.

\section{ANALYSIS: AN ADDITIONAL RECOMMENDATION: RECOGNIZING THE CONCEPT OF ADDICTION AS A MENTAL DISEASE}

\section{A. Addiction as a Mental Disease}

The inclusion of addiction to narcotics and dangerous drugs within Indiana's statutory definition of mental illness lays the groundwork for the implementation of civil commitment to address the issue of prenatal addiction. ${ }^{77}$ The Indiana Code defines mental illness, for purposes of the commitment statutes, as "[A] psychiatric disorder that substantially disturbs an individual's thinking, feeling, or behavior and impairs the individual's ability to function. The term includes mental retardation, alcoholism, and addiction to narcotics or dangerous drugs." 78 Further, advocates for those suffering from substance abuse addiction also push for the disorder's acceptance alongside other mental illnesses. ${ }^{79}$ The NAPW, an organization focused on human and civil rights for low-income women also recognizes that pregnant women who use drugs are struggling with addiction. ${ }^{80}$ Despite the central agreement that addiction is a mental illness, the legal distinction has yet to be used to bring additional state resources to the

76. Id. at 5 .

77. IND. CODE $§ 12-7-2-130$ (2007); see generally Karel, supra note 35 (noting that "[a] diagnosis of substance abuse provides no medical rationale for involuntary commitment" (quoting Michael Miller, M.D., of the Am. Soc. of Addiction Medicine))

78. $\S 12-7-2-130$.

79. See American College of Obstetricians and Gynecologists, ACOG Committee Opinion No. 422: At-risk Drinking and Illicit Drug Use: Ethical Issues in Obstetric and Gynecologic Practice, 112 OBSTETRICS \& GYNECOLOGY 1449, 1450 (2008) (noting the National Institute on Alcohol Abuse and Alcoholism and the National Institute on Drug Abuse's position that addiction is a "'brain disease' that should be included in a review of systems just like any other biologic disease process."); see also U.S. DEP'T OF HEALTH AND Human SERV., MeNTAl Health: A RePORT OF THE SURGEON GenERAL 9 (1999), available at $\mathrm{http}: / / \mathrm{www}$. surgeongeneral.gov/library/mentalhealth/pdfs/cl.pdf (noting that it is ironic that as advances in the field of mental health were achieved, "each condition was transferred from the mental health field to another medical specialty").

80. Angela Mapes Turner, Pregnant Addicts Blur Crime Debate: Authorities Waver on Punishment for Neglect, Abuse, J. GAZETTE, (Apr. 27, 2008), http://www.journalgazette.net/ apps/pbcs.dil/article?AID=/20080427/LOCAL/804270386. 
treatment and prevention of substance abuse. Specifically, this classification is uniquely suited for addressing the issue of prenatal substance abuse, so long as the proper procedures are followed.

\section{B. Civil Commitment}

\section{Indiana's Civil Commitment Framework}

Civil commitment is a process by which an individual can be detained in a mental health facility, usually for the individual's protection or for the protection of others, due to the individual's mental illness. ${ }^{81}$ The United States Supreme Court has held on more than one occasion that civil commitment is "a significant deprivation of liberty that requires due process protection." ${ }^{\prime 2}$ It is a practice which has long been employed in the United States for addressing the issues of the mentally ill. ${ }^{83}$ However, suffering from a mental disease alone will not result in the civil commitment of any Indiana resident, nor would a finding of dangerousness alone be sufficient. ${ }^{84}$ For an involuntary civil commitment proceeding to commence, it must be shown that an individual is mentally ill and either dangerous, or gravely disabled, as defined below. ${ }^{85}$

\section{a. Dangerous}

Indiana defines "dangerous" as "a condition in which an individual as a result of mental illness, presents a substantial risk that the individual will harm the individual or others." ers" within this definition of "dangerous" is key. "Others" would have to

81. Black's Law Dictionary 202 (8th ed. 2005) (defining the term "civil commitment" as "A commitment of a person who is ill, incompetent, drug-addicted, or the like, as contrasted with a criminal sentence.").

82. See, e.g., Addington v. Texas, 441 U.S. 418, 425 (1979).

83. See Linden, supra note 3 , at 121 ("Involuntary hospitalization has been a part of mental health law in this country for a century and a half.").

84. Kansas v. Hendricks, 521 U.S. 346, 358 (1997) ("A finding of dangerousness, standing alone, is ordinarily not a sufficient ground upon which to justify indefinite involuntary commitment. We have sustained civil commitment statutes when they have coupled proof of dangerousness with the proof of some additional factor, such as a 'mental illness' or 'mental abnormality."').

85. IND. CODE $§ 12-26-1-1$ (2007); see also C.J. v. Health and Hosp. Corp. of Marion Cnty., 842 N.E.2d 407, 410 (Ind. Ct. App. 2006) (noting that, in order to carry the burden of proof, an individual must be shown to be either dangerous or gravely disabled, both elements do not have to be proven).

86. IND. CODE $\S 12-7-2-53$ (2009) (emphasis added); see also BLACK's LAW DICTIONARY 336 (8th ed. 2005) (defining the term "imminently dangerous" as "reasonably certain to place life and limb in peril"; explaining that, in a certain legal context, "if a mental condition renders a person imminently dangerous to self or others, he or she may be committed to a mental hospital."). 
be statutorily interpreted or defined to include the unborn fetus of a pregnant substance abuser. It should also be noted that within the statute, the term "harm" is also undefined. Application of this statute within the framework of civil commitment would require acceptance that illegal drug use by a pregnant woman actually results in negative effects ("harm") on the unborn fetus ("other"). ${ }^{87}$ Further, "a trial court is not required to wait until harm has nearly or actually occurred before determining that an individual poses a substantial risk of harm to others." ${ }^{\prime 88}$ For the issue of prenatal substance abuse, this means that governmental intervention would not be dependent upon tangible evidence showing that the child has been harmed, such as a post-birth positive drug screen.

\section{b. Gravely disabled}

"Gravely disabled", is defined by statute as:

[A] condition in which an individual, as a result of mental illness, is in danger of coming to harm because the individual: (1) is unable to provide for that individual's food, clothing, shelter, or other essential human needs, or (2) has a substantial impairment or an obvious deterioration of that individual's judgment, reasoning, or behavior that results in the individual's inability to function independently. ${ }^{89}$

While individuals in Indiana have been deemed "gravely disabled"90 for conditions ranging from diabetes to the failure to take prescribed medications, ${ }^{91}$ the focus of this analysis is not on "gravely disabled." Alternative-

87. See Alexander Scherr, Daubert \& Danger: The "Fit" of Expert Predictions in Civil Commitments, 55 HASTINGS L.J. 1, 53-54 (2003) (surveying various statutory approaches to the term "harm"); see also BLACK's LAW DICTIONARY 595 (8th ed. 2005) (defining "harm" as "[i]njury, loss, damage; material or tangible detriment."); see also Harris \& Paltrow, supra note 26 ("Health care personnel may hear contradictory information about the effects of prenatal drug exposure or appropriate responses to addiction.").

88. C.J., 842 N.E.2d at 410; see also Matter of Commitment of Gerke, 696 N.E.2d 416, 421 (Ind. Ct. App. 1998) (holding, "We disagree with [the] implication . . . that a commitment premised upon a trial court's prediction of dangerous future behavior, without prior evidence of the predicted conduct, must be, in all cases, invalid. The old adage of "the dog gets one bite" does not, and should not, apply in the context of commitment proceedings, despite the severe restrictions on liberty imposed by commitment to a mental facility. ").

89. IND. CODE § 12-7-2-96 (2009).

90. In re Commitment of A.W.D., 861 N.E.2d 1260, 1265 (Ind. Ct. App. 2007) ("The evidence demonstrated A.W.D. is diabetic, requires two finger-prick tests of his blood sugar levels per day, and is unable to perform the tests on himself.").

91. In re Commitment of Bradbury, 845 N.E.2d 1063, 1065 (Ind. Ct. App. 2006) (where psychiatrist testified that Bradbury's failure to take prescribed medication resulted in symptoms such as "disorganized, aggressive, agitated, and delusional behavior."). 
ly, this analysis demonstrates that women who use illegal drugs during pregnancy are mentally ill and dangerous. Therefore, when women are found to be using drugs during pregnancy, an involuntary commitment proceeding is proper and justified under the statute.

\section{c. Procedure}

The thrust of this analysis is that, if addiction is a mental illness, and use of illegal drugs during pregnancy by women is deemed to constitute a "substantial risk" 92 of harm to "others," 93 in conformance with the above statutory definitions, it should be a logical and effective preventive measure to pursue the civil commitment of pregnant women who are abusing drugs. A framework for the civil commitment of those with mental illness is already in place in Indiana statute. Section 12-26-1-1 of the Indiana Code provides that an individual who is mentally ill and dangerous may be involuntarily detained or committed under one of four different procedures: immediate detention, emergency detention, temporary commitment, and regular commitment. ${ }^{94}$

Immediate detention is focused on giving law enforcement officers, who have reasonable grounds to believe an individual is mentally ill, dangerous, and in need of hospitalization and treatment, the ability to apprehend and transport individuals to the nearest appropriate facility. ${ }^{95}$ The next option, emergency detention, requires two statements: a statement by an applicant stating their belief that the individual in question is mentally ill, is either dangerous or gravely disabled, and is in need of immediate restraint; and another by at least one physician, based on an examination or an assessment of information given to the physician, that the individual in question is mentally ill, and either dangerous or gravely disabled. ${ }^{96}$ The detention of an individual under the emergency detention procedure is limited to seventy-two hours. ${ }^{97}$ If the emergency detention is deemed valid, the result is usually an order for either a temporary commitment or a regular commitment of the individual; procedures are discussed below.

Temporary commitment allows a person to be committed who is alleged to be mentally ill, and either dangerous or gravely disabled, for a period of not more than ninety days. ${ }^{98}$ A regular commitment, "the most restrictive form of involuntary treatment," applies to individuals alleged to

92. IND. CODE § 12-7-2-53 (2009).

93. Id.

94. IND. CODE § 12-26-1-1 (2009).

95. IND. CODE § 12-26-4-1 (2009).

96. IND. CODE § 12-26-5-1 (2009).

97. Id.

98. IND. CODE § 12-26-6-1 (2009).

99. J.S. v. Center for Behavioral Health, 846 N.E.2d 1106, 1111 (Ind. Ct. App., 2006) (quoting In re Commitment of R.L., 666 N.E.2d 929, 930 n.3 (Ind. Ct. App., 1996)). 
be mentally ill, and either dangerous or gravely disabled, and "whose commitment is reasonably expected to require custody, care, or treatment in a facility for more than ninety (90) days." 100

The immediate detention procedure, because its duration would not cover the full term of the pregnancy, would likely have limited applicability to the issue here, although there are certain unique instances where the statute could be applied to prenatal substance abuse. In contrast, the emergency detention procedure could conceivably be the main route to the civil commitment of prenatal substance abusers. However, this option assumes that someone close to the pregnant drug abuser would cross the line from gently suggesting an end to the substance abuse, to forcing the pregnant drug user to receive help, in the best interest of the fetus. Typically only a close friend or family member would know enough about the woman's situation to be able to provide meaningful information to those in a position to act. For example, in the case of In Re Commitment of J.B., the applicant requesting J.B.'s emergency detention was a deacon in J.B.'s church who knew about his bipolar disorder and with whom J.B. had a disturbing conversation where he expressed a desire to kill something and hit his exwife. $^{101}$ However, there is no doubt that there would be feelings of betrayal at such a move by a close friend or family member, especially in a situation as personal as pregnancy. Furthermore, reliance on civil commitment to help stop the use of illegal drugs by pregnant women may not be ideal, but it is an option, and it would be a start.

Temporary and regular commitments would most likely become the standard for prenatal substance abusers. The procedures for temporary and regular commitments are similar to the procedure for emergency detentions. ${ }^{102}$ For both temporary and regular commitments, the original petition must be paired with a statement from a physician attesting to the mental illness and either the dangerousness or grave disability of the individual. ${ }^{103}$ However, it should be noted that for regular commitments, the physician's statement must be based on an actual examination of the individual within thirty days prior to submission of the statement. ${ }^{104}$ For a temporary commitment, the decision is left to the court hearing the proceedings as to whether or not to appoint a physician to examine the individual. ${ }^{105}$

A hearing must be held under both procedures, ${ }^{106}$ and it is left to the court to make the determination of the individual's mental illness and a

100. IND. CODE § 12-26-7-1 (2009).

101. In re Commitment of J.B., 766 N.E.2d 795, 796 (Ind. Ct. App., 2002).

102. See IND. CODE § 12-26-5-1 (2009).

103. IND. CODE § 12-26-6-2(c) (2009); IND. CODE § 12-26-7-3 (2009).

104. IND. CODE $§ 12-26-7-3$ (a) (2009).

105. IND. CODE § 12-26-6-6 (2009).

106. IND. CODE § 12-26-6-4; IND. CODE § 12-26-7-4 (2009). 
finding of dangerousness to the individual or others. ${ }^{107}$ The burden is on the state in these proceedings to show by clear and convincing evidence that the facts warrant commitment. ${ }^{108}$ The "clear and convincing evidence" standard can only be met by a showing that the person's alleged dangerous behavior would not occur but for the person's mental illness. ${ }^{109}$ For a regular commitment to terminate, further action is required. Such a commitment must be continuous until either the holding facility discharges the individual or the court enters an order terminating the commitment. ${ }^{10}$ Therefore, the type of commitment required in a situation involving prenatal substance abuse would have to be determined by the court, most likely based on the gestational progress of the drug abuser's pregnancy.

\section{Civil Commitment in Other States}

The standards and procedures for civil commitment vary among the states. ${ }^{111}$ Many states have statutes similar to Indiana law, while a few states take the reach of governmental intervention even farther. Minnesota, New Jersey, South Dakota, and Wisconsin all have statutes which provide for civil commitment and involuntary detention of mothers found to be actively using illegal drugs while pregnant. ${ }^{112}$ Furthermore, two other states, North Dakota and Oklahoma, have statutes authorizing the civil commitment of women who abuse alcohol during pregnancy. ${ }^{113}$

107. IND. CODE § 12-26-6-8; IND. CODE § 12-26-7-5 (2009).

108. In re Turner, 439 N.E.2d 201, 204 (Ind. Ct. App. 1982); see Addington v. Texas, 441 U.S. 418, 432-33, (1979) (finding that instruction used in Texas proceeding for commitment due to mental illness employing the standard of "clear, unequivocal, and convincing" evidence, was constitutionally adequate, but that the "determination of the precise burden equal to or greater than the 'clear and convincing' standard which we hold is required to meet due process guarantees is a matter of state law").

109. G.Q. v. Branam, 917 N.E.2d 703, 707 (Ind. Ct. App. 2009).

110. $\S 12-26-7-5(\mathrm{~b})$.

111. Addington, 441 U.S. at 431 (noting that "[a]s the substantive standards for civil commitment may vary from state to state, procedures must be allowed to vary so long as they meet the constitutional minimum."); see also Kansas v. Hendricks, 521 U.S. 346, 359 (1997) ("[W]e have never required state legislatures to adopt any particular nomenclature in drafting civil commitment statutes.").

112. See MinN. Stat. ANN. § 253B.05 (West 2007) (emergency admissions); MinN. STAT. ANN. $§ 626.5561$ (West 2009) (reporting of prenatal exposure to controlled substances); § 626.5562 (toxicology tests required); see also N.J. STAT. ANN. § 30:4C-11 (West 2008) (application for care or custody, verification and investigation, and acceptance of care or custody); see also S.D. CoDIFIED LAWs § 34-20A-63 (2009) (emergency commitment and grounds); S.D. CoDIFIED LAws $\S 34-20 A-70$ (2009) (petition for involuntary commitment, appointment of attorney for applicant, procedure, and grounds); see also WIS. STAT. $\S 48.133$ (2008) (jurisdiction over unborn children in need of protection or services and the expectant mothers of those unborn children); WIS. STAT. $\$ 48.193$ (2008) (taking an adult expectant mother into custody); $\S 48.19(1)(\mathrm{cm})$ (taking a minor expectant mother into custody); $\S$ $48.205(1 \mathrm{~m})$ (criteria for holding a child or expectant mother in physical custody); $\S$ 48.205(1)(d) (criteria for taking pregnant minor into custody).

113. Pregnancy and Alcohol: Civil Commitment: Policy Description, NATIONAL 
The procedure in Wisconsin, as perhaps the first state to use civil commitment in the effort to curtail exposure to illegal substances, is particularly interesting and detailed. Its three-stage approach proceeds through the rights and requirements involved in the initial taking of an individual into custody, to the brief holding of an individual in physical custody, to the continued physical custody of an individual. ${ }^{114}$ As different as the procedures in these states might be, "all of these commitment and custody provisions are designed to protect the fetus via the involuntary restriction of the pregnant woman's action or conduct."115 But the farthest reaching statute to address the issue is a South Carolina statute, under which the use of illegal drugs while pregnant can be prosecuted as a felony. ${ }^{116}$

\section{Legislative Will and Public Policy}

\section{a. Recent Indiana legislation}

The Indiana General Assembly seems to be open to passing legislation that extends the protection of unborn children in the state, in both civil and criminal terms. Effective July 1, 2009, the Indiana Wrongful Death statute was amended to include the phrase, "a fetus that has attained viability," in the definition of "child." 117 The amendment was enacted with this new inclusion in direct response to a 2009 Indiana appellate court decision. In

INSTITUTE ON ALCOHOL ABUSE AND ALCOHOLISM, http://www.alcoholpolicy.niaaa.nih.gov/ Alcohol_and_Pregnancy_Civil_Commitment.html (last visited Jan. 2, 2011) ("As of January 1,2008 , five jurisdictions have statutory authorization for the civil commitment of women who abuse alcohol during pregnancy: Minnesota, North Dakota, Oklahoma, South Dakota, and Wisconsin.").

114. Id. ("Wisconsin's child welfare laws provide for involuntary civil commitment to a variety of placements including a treatment facility, jail, and a relative's home. In Wisconsin there are three stages leading to a judicial commitment. In the first stage, a woman is taken into protective custody, usually by law enforcement or child protective services. In the second stage, in cases in which there is a substantial health risk to the fetus, the woman may be held (detained) in protective custody for up to 48 hours. In the third stage, if custody is sought for a sustained period of time (i.e., a period longer than provided for in the second stage), the woman is entitled to legal representation and a hearing at which a court determines whether it will enter an order for her continued custody. ").

115. Id.

116. S.C. CODE ANN. \$16-3-85 (2008); see also Karel, supra note 35 ("Although the South Carolina law could be applied to women who test positive for alcohol or tobacco, prosecutors there have limited application to women who test positive for illicit drugs, including cocaine and marijuana").

117. IND. CODE \& 34-23-2-1 (2007); see also BLACK's LAW DictionaRY 197 (8th ed. 2005) (defining "child" as "1. A person under the age of majority. 2.; Hist. At common law, a person who has not reached the age of 14. 3.; A boy or girl; a young person. 4.; A son or daughter. 5.; A baby or fetus." (emphasis added); it is interesting to note that "a fetus that has attained viability" would, quite literally, satisfy all of these definitions); see also Harris \& Paltrow, supra note 26 (noting that expanded civil wrongful death statutes "hold only third parties accountable for causing pregnancy loss. Courts have declined to extend these laws to pregnant women, recognizing that pregnant women's actions with respect to their own bodies raise different legal and policy issues"). 
Ramirez v. Wilson, a woman nine months pregnant was killed in a head-on car collision, and the baby died in utero. ${ }^{118}$ The court held that a full-term, viable unborn fetus was not a "child" for purpose of the wrongful death statute. ${ }^{119}$ The statute was amended to thwart the Ramirez court's interpretation of the statute. Another recent change in Indiana law was the amendment to the crime of murder, which now includes the charge that "[a] person who knowingly or intentionally kills a fetus that has attained viability commits murder." 120 Further, the Indiana feticide statute, which allows criminal prosecution for a person who "knowingly or intentionally terminates a human pregnancy with an intention other than to produce a live birth or to remove a dead fetus," was also amended in 2009 , increasing the maximum punishment from eight years to twenty years. ${ }^{121}$ These changes in Indiana criminal law were direct results of a tragic event in 2008 , when a bank teller who was five months pregnant with twins lost both fetuses after she was shot in the abdomen during a bank robbery. ${ }^{122}$ The bank robber was sentenced to fifty-three years, eight years of which stemmed from two feticide convictions. ${ }^{123}$ The willingness to change the law in Indiana, within both the civil and criminal contexts, is most welcome because one of the loftiest goals a state can strive for is the protection of those who cannot protect themselves, especially protection for unborn children.

\section{b. Public Policy and the United States Supreme Court}

It would seem that this author's interpretations and opinions on the issue are, in some ways, in agreement with the United States Supreme Court's interpretation: "[T]he State does have an important and legitimate interest in preserving and protecting the health of the pregnant woman ... it has still another important and legitimate interest in protecting the potentiality of human life." 124 It should be noted that even though the Court in Roe $v$. Wade concluded that a fetus is not a "person" and therefore does not en-

118. Ramirez v. Wilson, 901 N.E.2d 1, 2 (Ind. Ct. App. 2009).

119. Id. at 3 .

120. IND. CODE § 35-42-1-1 (2009).

121. IND. CODE $\S 35-42-1-6$ (2009) (note that this law does not apply to an abortion performed in compliance with Indiana law).

122. See Rick Callahan, Bid Made to Add Fetuses to Murder Law, News SENTINEL (May 1, 2008), http://www.news- sentinel.com/apps/pbcs.dll/article?AID=/SE/ 20080501/NEWS/805010327; see also ABCNEWS.COM, Man Gets Prison for Shooting Pregnant Bank Teller, Feb. 13, 2010. http://abcnews.go.com/US/ wirestory? id= 9828628\&page $=1$.

123. See ABC News.com, supra note 122.

124. Roe v. Wade, 410 U.S. 113, 162 (1973); but see April L. Cherry, Roe's Legacy: The Nonconsensual Medical Treatment of Pregnant Women and Implications for Female Citizenship, 6 U. PA. J. ConsT. L. 723, 724 (2004) (arguing that the Court's recognition in Roe v. Wade of a "compelling state interest" in fetal life has "in some ways led to the derogation of women's choices, women's autonomy, and, consequently, women's citizenship"). 
joy any constitutional rights under the Fourteenth Amendment, ${ }^{125}$ it did recognize that fetuses may enjoy protection from other, non-constitutional sources. $^{126}$ Moreover,

[t]he state has a legitimate interest under its parens patriae powers in providing care to its citizens who are unable because of emotional disorders to care for themselves; the state also has authority under its police power to protect the community from the dangerous tendencies of some who are mentally ill. ${ }^{127}$

Further, "[t]he State may take measures to restrict the freedom of the dangerously mentally ill. This is a legitimate non-punitive governmental objective and has been historically so regarded." 128 It is with such statements of policy and constitutional support from our nation's highest judicial authority, and the apparent willingness of the Indiana General Assembly to enact change, that the following recommendation for action concerning the issue of prenatal substance abuse is presented.

\section{SOLUTION PRESENTED}

\section{A. Application of Existing Law}

Indiana needs to apply existing statutes to the issue of prenatal substance abuse, expanding and refining the civil commitment response without the need for criminal prosecution. Chemical addiction, under Indiana law, can and should be treated as a mental illness. ${ }^{129}$ In the State of Indiana, those who suffer from mental illness and are found to be a danger to themselves or others, can be committed to the appropriate facility for treatment. ${ }^{130}$ Such action is narrowly tailored and serves a compelling state interest. ${ }^{131}$ In Kansas v. Hendricks, the Supreme Court noted, "We have consistently upheld such involuntary commitment statutes provided the confinement takes place pursuant to proper procedures and evidentiary

125. Roe, 410 U.S. at 158.

126. Id. at 162 (commenting that "unborn children have been recognized as acquiring rights or interests by way of inheritance or other devolutions of property").

127. Addington v. Texas, 441 U.S. 418, 426 (1979).

128. Kansas v. Hendricks, 521 U.S. 346, 363 (1997).

129. See IND. CODE § 12-7-2-130 (2007).

130. IND. CODE $\S 12-26-1-1$ (2009).

131. See generally Zablocki v. Redhail, 434 U.S. 374, 388 (1978) ("When a statutory classification significantly interferes with the exercise of a fundamental right, it cannot be upheld unless it is supported by sufficiently important state interests and is closely tailored to effectuate only those interests."). 
standards. It thus cannot be said that the involuntary civil confinement of a limited subclass of dangerous persons is contrary to our understanding of ordered liberty." $" 132$

Not only would civil commitment of pregnant substance abusers provide them with treatment throughout the pregnancy, but it could also provide detoxification in a facility with proper medical supervision to minimize the risk to the unborn fetus. The goal would not be long-term civil commitment, but rather a commitment which places the mother-to-be and the child in the best position to succeed in life together: one free from the oppressive existence that is drug addiction, the other free from exposure to illegal drugs during gestation. Civil commitment offers a better solution to the problem of substance abuse during pregnancy because it "directly addresses the problem, lacks punitive aspects, and offers a potentially effective and long-term solution to gestational substance abuse."133

\section{B. Clarification and Expansion of Existing Law}

Clarification and expansion of current statutes could be as simple as an amendment which states that "others," for purposes of the definition of "dangerous" under Section 12-7-2-53 of the Indiana Code, includes "a fetus that has attained viability," similar to the way the Indiana Wrongful Death statute was recently amended. ${ }^{134}$ Facilities to house individuals during treatment and postpartum already exist, but the "red tape" which impedes access to these facilities could be substantially reduced through direct civil commitment. ${ }^{135}$ The 2009 Prenatal Substance Abuse Commission report indicated there are underutilized residential facilities in the state. ${ }^{136}$ When underutilization of resources is combined with the estimates that the costs of lifetime care for children who are born after surviving prenatal exposure to alcohol or illegal drugs range from $\$ 750,000$ to $\$ 1.4$ million, the monetary incentive for this solution speaks for itself. ${ }^{137}$ Where appropriate treatment facilities are not available in an individual's community, Indiana's five psychiatric hospitals that accept adult patients could be ideal, especially the Richmond State Hospital's large substance abuse services

132. Hendricks, 521 U.S. at 357 ; see also J.S. v. Ctr. for Behavioral Health, 846 N.E.2d 1106, 1114 (Ind. Ct. App., 2006) ("The Indiana statutory scheme providing for judicial review of a proposed treatment plan when a patient objects to the course of treatment is constitutionally sufficient to satisfy the due process requirement of a judicial hearing by an independent decision maker to evaluate the competing interests reflected.").

133. Kristen Rachelle Lichtenberg, Comment, Gestational Substance Abuse: A Call for a Thoughtful Legislative Response, 65 WASH. L. REV. 377, 378 (1990).

134. IND. CODE § 34-23-2-1 (2009).

135. See IND. PRENATAl SUbSTANCE AbUSE COMM'N, supra note 1, at 11.

136. Id.; see also ZOLLINGER, ET AL., supra note 3, 186-234 (listing an inventory of treatment programs in Indiana by county, with the type of services provided and contact information for each program).

137. KALOTRA, supra note 74. 
unit. $^{138}$ Further, Indiana could facilitate priority access to state-funded substance abuse treatment programs for pregnant women, as has been done in nine other states, and prohibit publicly-funded treatment facilities from discriminating against pregnant women, as four other states have done. ${ }^{139}$

\section{A Possibility for Future Legislative Action and Response to Opposing Viewpoints}

\section{For Consideration: A Point of Agreement with the Prenatal Substance Abuse Commission Final Report}

A possibility for the Indiana General Assembly to consider is a uniform screening procedure for all pregnant women in Indiana to determine levels of illegal drug use, similar to one of the recommendations of the Prenatal Substance Abuse Commission. ${ }^{140}$ The idea behind a uniform screening procedure is to ensure that those women who do seek out medical supervision during their pregnancies are at least asked the questions regarding possible alcohol, tobacco, or illegal drug use. A uniform screening procedure would not necessarily need to become state law, however, providing minimal funding might help to persuade prenatal medical providers to utilize a question-and-answer verbal process with their clients. One would hope that doctors are not simply assuming a pregnant woman is not using alcohol, tobacco, or illegal drugs unless they are informed otherwise. One Indiana non-profit agency, The Indiana Perinatal Network, has already developed a DVD-based training aid for physicians, which focuses on integrating screening and treatment of alcohol, tobacco, and illegal drug use into routine prenatal care. ${ }^{141}$ After women are questioned about any alcohol, tobacco, or illegal drug use, any self-reported use could be addressed immediately and discretely, hopefully within the confines of the doctorpatient relationship and without the need for judicial intervention. However, if that is not possible, civil commitment could become an option.

138. Richmond State Hosp., Facility Fact Sheet, INDIANa Family AND Social SERviceS ADMINISTRATION: Division OF MENTAL HEAlTH \& ADDiction, http://www.in.gov/ fssa/dmha/files/RSH_fact_sheet_09.pdf (last visited Jan. 2, 2011) ("The recovery philosophy of the program is based on a recovery model of dependency as a disease with special attention to the Stages of Change.").

139. The Guttmacher Inst., State Policies in Brief: Substance Abuse During PREGNANCY 1 (2010), available at http://www.guttmacher.org/statecenter/spibs/ spib_SADP.pdf; see also ZoLLINGER, ET AL., supra note 3, at 6 ("[M] any [Indiana] programs are not accessible to pregnant women especially if they have other children and/or need inpatient care.").

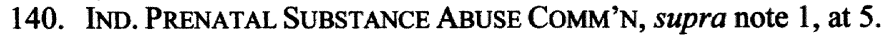

141. Substance Use, INDIANA PERINATAL NETwORK, http://www.indianaperinatal.org/ sections/substance_use.php (last visited Jan. 2, 2011). 


\section{Opposing Viewpoints}

The most common argument against is the above proposal is: wouldn't this type of system discourage a pregnant woman even more from pursuing medical attention if there is a chance she will have a positive urine screen, or other indicator, which could lead to a temporary period of commitment? Obviously, this is a strong possibility, especially with pregnant women who already have other children as well. There are several challenges that would be involved in correctly identifying women for whom the application of the civil commitment framework, or even voluntary treatment, would be appropriate. ${ }^{142}$ This opposition argument was succinctly summarized by the American Civil Liberties Union:

A decade ago, we saw a rash of cases in which government officials zealously embraced a misguided mission to protect fetuses by attempting to control the conduct of pregnant women. Some women were forced to accept unwanted medical treatment; others were punished for their conduct during pregnancy. Inevitably, such actions backfire: women who fear the government's "pregnancy police" will avoid prenatal care altogether, and both they and their fetuses will suffer as a result. ${ }^{143}$

However, the solution proposed here is not presented as a cure-all for the issue of prenatal substance abuse. Rather, it is presented as an option, which in some ways is already available in Indiana. If it is successful in preventing even one unborn fetus from being exposed to the crippling effects of illegal substances, it will have done some good. The interests of the mother would also be served, especially in those instances where the drug abuser truly wants to address her addictions. In the current approach, the courts usually become involved only after a mother gives birth to a child who tests positive for illegal drugs, ${ }^{144}$ the result of which would almost in-

142. See ZolLINGER, ET AL., supra note 3 ("One of the most difficult challenges of ... treatment is identifying women using [alcohol, tobacco, or illegal drugs] and drawing them into care.").

143. Coercive and Punitive Governmental Responses to Women's Conduct During Pregnancy, AMERICAN CIVIL LIBERTIES UNION (Sept. 30, 1997), http://www.aclu.org/ reproductive-freedom/coercive-and-punitive-governmental-responses-womens-conduct-duringpregnancy; see also Karel, supra note 35 ("Legal threats against pregnant women with drug problems cause them to avoid prenatal care for fear of detection, which means that the risk to mother and fetus from drug use is compounded by an absence of prenatal care."). But see Linden, supra note 3, at 110 (discussing how "both criminal and tort law have moved in the direction of recognizing fetal interests").

144. See IND. CODE § 31-33-5-4 (2008). 
variably lead to the termination of parental rights. ${ }^{145}$ The solution presented here would be an opportunity for the mother to address her addiction prior to the birth of her child, perhaps presenting an opportunity for the mother and child to remain together after the birth in a way that would not be likely to occur under the current legal framework. ${ }^{146}$ Neither criminalization nor the use of child protection laws adequately promotes both healthy births and the preservation of the mother-child relationship. ${ }^{147}$

Next is the question: wouldn't this put a medical professional in an adversarial role to the patient? This view is understandable, and the dilemma has certainly been noted by medical professionals contemplating the possible moral, ethical, and legal considerations. ${ }^{148}$ However, as a positive, it would put the medical professional in an advocate role for the unborn child. $^{149}$ Further, many states already statutorily require medical professionals to report suspected prenatal substance abuse. ${ }^{150}$ Indiana could implement a similar statutory requirement.

Critics of commitment look to medical professionals for support of their perspective. For example, "leading medical and public health groups - such as the American Academy of Pediatrics, the American Medical Association, the American Public Health Association and the March of Dimes-all oppose punitive responses to prenatal drug use," ${ }^{151}$ including

145. See IND. CODE § 31-33-7-4 (2008).

146. See David F. Chavkin, "For Their Own Good": Civil Commitment of Alcohol and Drug-Dependent Pregnant Women, 37 S.D. L. REv. 224, 248-49 (1992) ("[R]esearch on mandatory treatment programs indicates that such treatment can be effective. The significant factor appears to be not the voluntary or mandatory nature of the treatment, but rather the characteristics of the treatment provided, whatever the impetus to seek care."); see also Wendy Chavkin, Help, Don't Jail, Addicted Mothers, N.Y. Times, July 18, 1989, at A21 (where the author reports, "Most pregnant women, including addicted ones, want very much to do what's right for their future children. At a drug treatment program in New York City, 30 addicted women told me that they felt so guilty about using drugs while pregnant that they used more drugs to escape the feelings of self-loathing.").

147. Linden, supra note 3 , at 120.

148. See Harris \& Paltrow, supra note 26, at 1698 ("Civil commitment laws and civil child welfare laws addressing the subject of drug use during pregnancy may intensify confusion regarding physicians' legal obligations.").

149. See generally id. ("Some bioethical models assert that physicians have moral obligations to fetal 'patients,' separate from obligations to pregnant women. These models may imply that fetuses have a right to medical attention independent of pregnant women's consent."); see also Linden, supra note 3, at 115 (explaining that under the theory of "cultural feminism," "society must not adopt adversarial approaches which view the mother and fetus as distinct legal entities with adverse interests and assume that the state must protect the fetus from the mother.").

150. THE GUTTMACHER INST., supra note 139 (current states requiring reporting do not include Indiana); see also Karel, supra note 35 ("Mandatory reporting approaches are problematic because they place the physician in an awkward position regarding the doctor-patient relationship and because they tend to [drive away] people who don't want to be subjected to reporting"; "Good health care demands trust between the doctor and the patient.").

151. Dailard \& Nash, supra note 58, at 6; see also Karel, supra note 35 ("Use of criminal sanctions for women who use drugs during pregnancy has been rejected by most public health organizations"). 
civil commitment and criminal sanctions. However, rarely is it the judicial practice to equate civil commitment to a criminal sanction. Civil commitment is defined as a "commitment of a person who is ill, incompetent, drugaddicted, or the like, as contrasted with a criminal sentence." ${ }^{, 152}$ Indeed, the United States Supreme Court has held, "In a civil commitment state power is not exercised in a punitive sense. . . . a civil commitment proceeding can in no sense be equated to a criminal prosecution," 153 as well as stating that "the mere fact that a person is detained does not inexorably lead to the conclusion that the government has imposed punishment."154 However, with regard to commitment in general, a key point is made that should be kept in mind, but which may become less of a concern as society begins to understand and accept the proposition that those suffering from addiction are actually suffering from a form of mental illness:

[I]t is indisputable that involuntary commitment to a mental hospital after a finding of probable dangerousness to self or others can engender adverse social consequences to the individual. Whether we label this phenomena "stigma' or choose to call it something else is less important than that we recognize that it can occur and that it can have a very significant impact on the individual. ${ }^{155}$

Indiana courts have reflected this sentiment, stating, "The question of how persons subject to involuntary commitment are treated by our trial courts is one of great importance to society. Indiana statutory and case law affirm that the value and dignity of the individual facing commitment or treatment is of great societal concern." 156 In the implementation of the solution presented here, these concerns must be kept in mind.

\section{CONCLUSION}

Indiana's current approach to the problem of illegal drug use during pregnancy does not acknowledge the increasingly validated assertion that addiction is a mental illness. With the status-quo approach, most recently recommended by the Indiana General Assembly's Prenatal Substance

152. BLACK's LAW Dictionary 202 (8th ed. 2005) (emphasis added).

153. Addington v. Texas, 441 U.S. 418, 428 (1979); see also Kansas v. Hendricks, 521 U.S. 346, 363 (1997) ("The Court has, in fact, cited the confinement of 'mentally unstable individuals who present a danger to the public' as one classic example of nonpunitive detention." (citing United States v. Salerno, 481 U.S. 739, 748-49 (1987)).

154. Salerno, 481 U.S. at 746.

155. Addington, 441 U.S. at 425-26.

156. In re Commitment of J.B., 766 N.E.2d 795, 798 (Ind. Ct. App., 2002). 
Abuse Commission, of raising awareness and focusing on prevention and treatment, the State of Indiana fails to use all its resources to prevent prenatal exposure to illegal drugs. While a continued focus on prevention and treatment for pregnant substance abusers is at least an attempt to mitigate the issue, and by all means the most common governmental approach, failure to exercise judicial intervention in appropriate circumstances is a grave disservice to the unborn fetuses that are being affected by the horrors of prenatal substance abuse.

The State of Indiana should be bold in its approach to the issue of prenatal substance abuse, following in the footsteps of several other Midwestern states. The continued failure by the State of Indiana to utilize all available resources leaves it open to a potentially highly publicized instance of prenatal illegal substance exposure, which would result in a public backlash causing a kneejerk reaction by the legislature to enact more drastic legislation. The approach outlined above, which lays out the groundwork and procedure by which certain women who are found to be pregnant and currently addicted to drugs can be committed to an appropriate residential treatment provider, should be focused on the most serious of cases. Addiction is a mental illness, and should be treated as such. An addiction which affects an unborn fetus is a circumstance where the pregnant user is both mentally ill and dangerous to the point of presenting a substantial risk to others, specifically the unborn fetus. This proposed approach is a narrowly tailored governmental intervention which serves a compelling state interest in the protection of viable unborn fetuses, without the challenges and adversity which would result from criminal sanctions. 
